計 討 る

で理加と会会

あ的えが論計

る。計よで 諞画

(1) 論 。占漸関

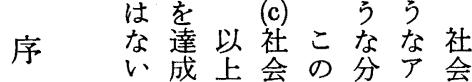

標主。進る

設槈本的従

設す論婳来

定る社入气議

(2) 丟 る含誐

設計 前㭆は

定画に勇 大

さ次こ导く

たの市只

貝標う 占总合

亳— 議吉的

琴連泥画

すのつ論

る過程芯芯

め㤂 若つ导

手成分 分导

経う点こる、結しす

験こらの (6) 笨て心

的と合実定、て

にでて理行寒そリ

分あ最的後現のス

析るも計に守手卜

すす重画結る段苸を

とななのの段選

いわの問評を択 プ

うちは題価選しす

よ拿合点孛行たる

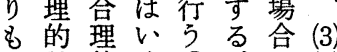

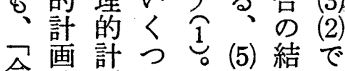

含画計 論画年) 結で

理は論あのをス

的は喻る 手导不

な社賛そ。段气゙!

会会範そ勇確

㻅㻅的れ 角確

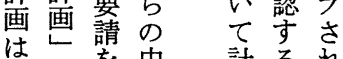

はと市中計る就

かとしで画市た

あうて本亲尔各

る現る省行ま段

べ象と視すしに

こ尔の計目析プ計

々る予画的枠口画

メ備 の の組 | に

目力作担たの千関

的二業いめ構をす

をズを手の築避る

実公経で予老け従

現をたあ備め、来

す中上る作ざ社の

る心で拡業す衸議

たに、大とこ会論

め分社意しと亩 の

の析会思て、゙画多

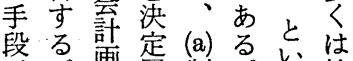

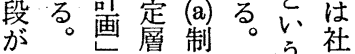

必そを蓹社会

して制内部視会覞

合の情析分 象対

理分報をら経す

的析報行只験る

に処 う。社験規

選通理。会学範

択じ視構 告 的

さて点造 対要

る社吕 概 象請

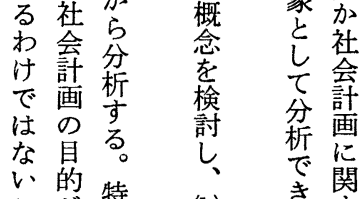

こが特 (b) き䡒

之必に構少る

なし社造淛経

なと会制 社験

社計

奛会画

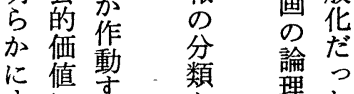

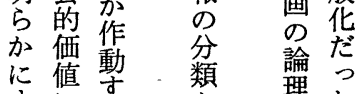

すにす

る。原

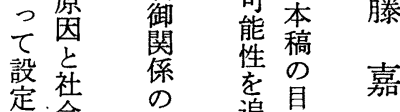

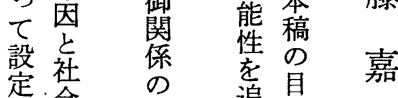

さ馀分追的 偷

る画盇 ぎ

$\begin{array}{lll}\text { け目 行 } & \text { る } \\ \text { で的 } & \text { よ } & \end{array}$

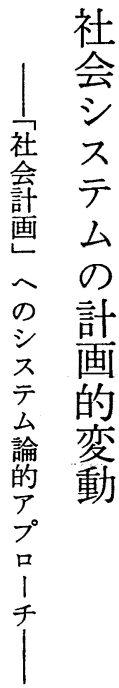




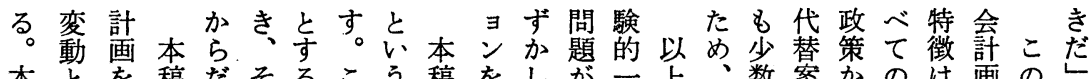

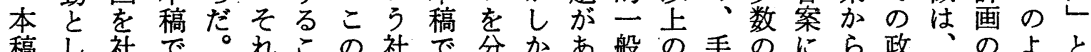

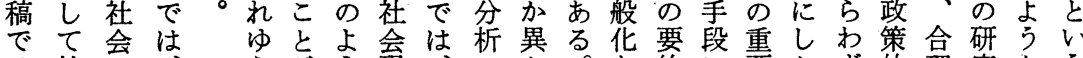

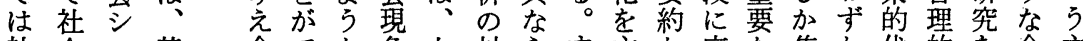

社会 ス基合でな像上対らす主か応な焦加代的を合主 会構テ本理きアを述象なな張らしも点し替計指理張 構造 $厶$ 的. 的、プ分しといわしわてのをか案画向的を 造ののに計ま口析たす方ちてか目に当つの論す計す の変意、画た 変動図自論社 チ水うこえ進るよがらな. 怘底対論

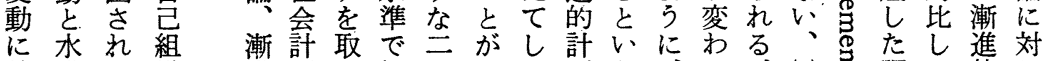

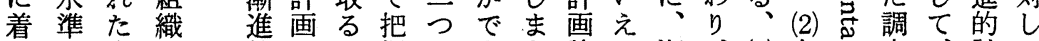
目変変 シ 的のこ握のきう論よ漸、(3) 各气查、計て 寸数動 ス 計論と寻了なたでう進目目政し次画 る。值とテ画理でるプくめは。的標標策異評の論漸

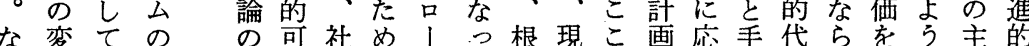

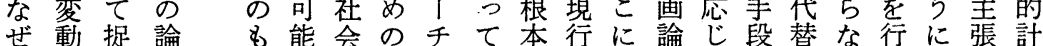
なと㻎つ性計分をし的の漸はて喿案いらます画 らいるを問を画析避まな政進社手密に比のとる論 後う。援題追を枠澼 引社策的会段接対較でめ社は 述三社角を求経組、合会と計計がにす的はら会よ すつ会しう方験のつ岂的代画画変関る少なれ計り

るの方つリる科構社。イ替論にお係結数くよ画経

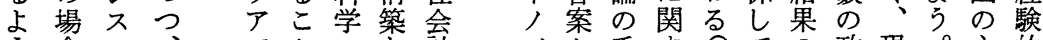

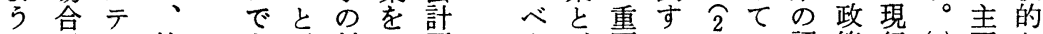

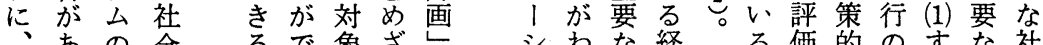

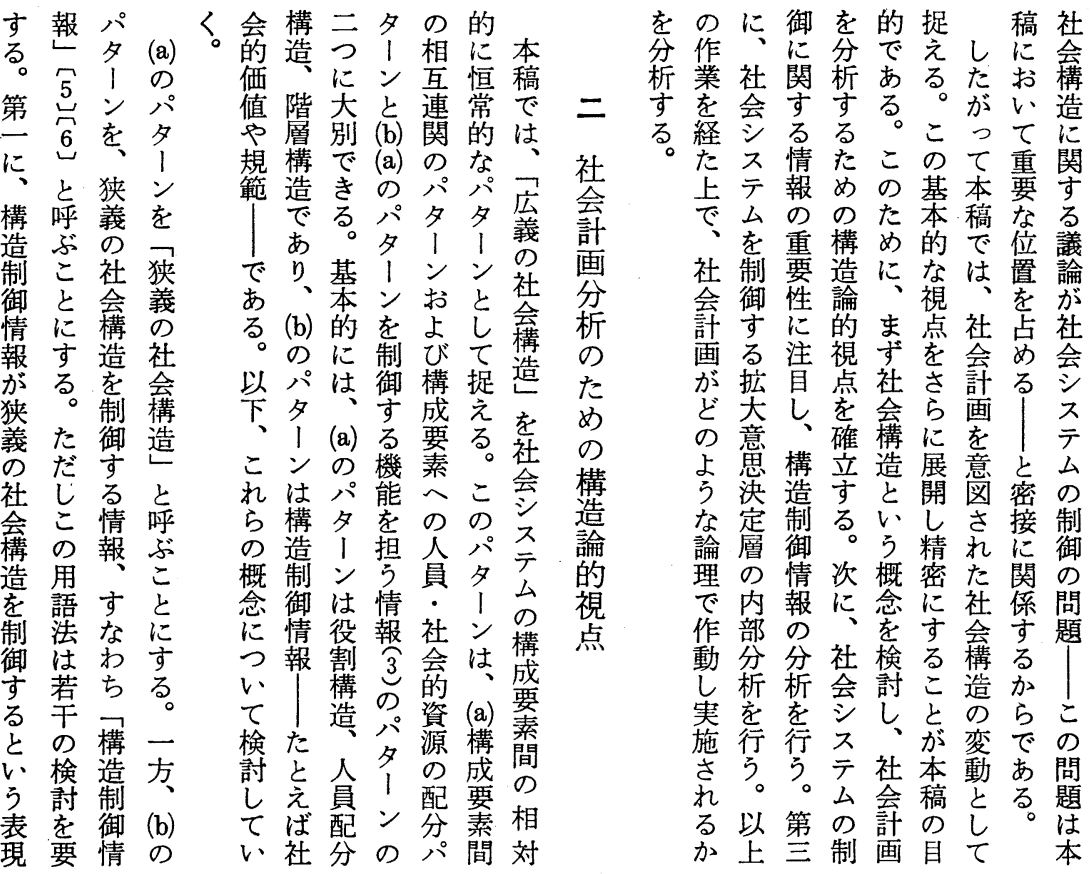




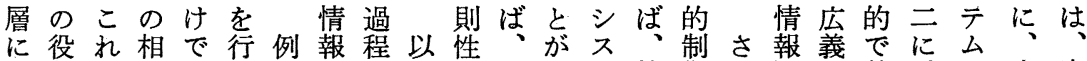

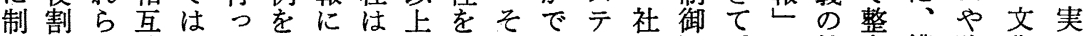
御期の連なて挙よ狭がものき会社合構狭化は さ待狭関くいげつ義社つパるの音と本い会的造義シ正 れと義公るるて会こタ。水スい稿う構な制の確 ていの夕職とうへ社シと、つ準テうで用造パ御社テで いう社、業し。文会スにンま変么考は語に夕情会么は る構会ンへよ社花構テなにり数のえ含、報構やな 造構とのう。会方造么る。基兮值狭を狭角まンは造拡く 制造い人。シスにに 御はう員こステょお 情人狭 $の$ テムうけ 報員 義社場么やてる に・の会合の拡制制 よ社社的、成大御御 ○会会資生員意さ関 て的構源産吕思れ係 文資造の活様 決、の 化源に配動々 定 狭概 シの制分はな層義略 ス配御パラ職にので テ分さタン業し社あ 厶規れ、ダに制会る や則てンム従御構

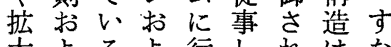
大よるよ行しれはな 意び。びわ生る。構わ 思職さ職れ産。造ち 決業ら業る活制社 定間に間わ動御会 以、変の用のるる形ン制意一 てン動社す社こ。成ダ御葸種 変と门会る会と以し允す決の 動し構。構に上てにる、定簡 等七造彼造しのい存、層略 るの制はのによ二る在とが的 プ 狭御社考関う点。すい構表 口義す会えし。老こるう造現 セのる過をて、確のの表制で ス社制程本、認意で現御あ と会御稿今味は告情る。 し構機 媾文田たでな方報。 て造構 時文 $气$ 上構く正よ節

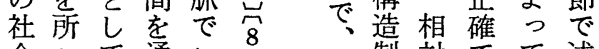
会与て通解岕㫼対でて述

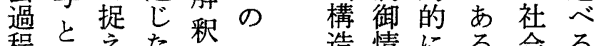
程すえた梏情にる。会る 御会規れこ会れ造御は常第スう

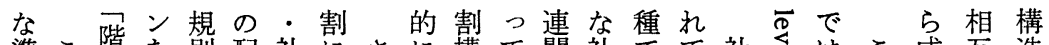

準こ階を則配社にさに構て関社でて社怘はこ成亩造構 拠の構形分公会て恒造、公会あい会さなれる。連の造 点よ梏成

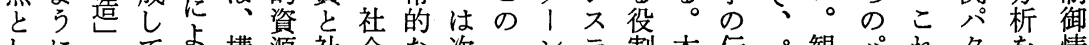

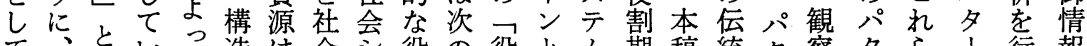

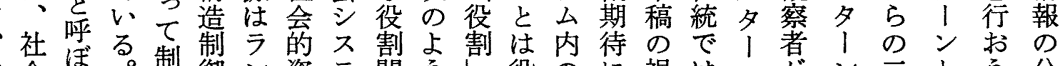

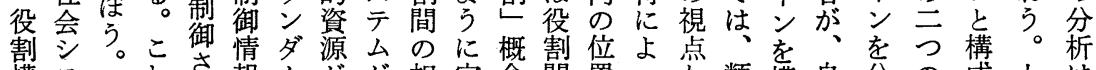
構 ス れさ報么がが相定念間置つか類構自分の成上は 造テられ、のに配作互義をの㐫てら型成芑析パ要述次

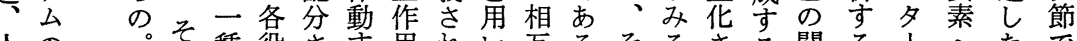
人の パそ種役さ等用れい互るそるさる関る、へだ 員狭夕名で割れるのるて作。ことれ要心場ンのよ行

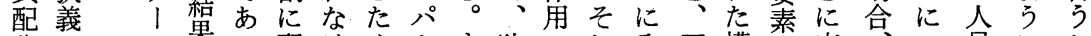

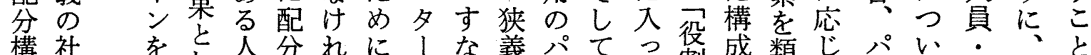

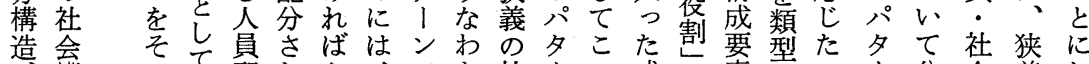

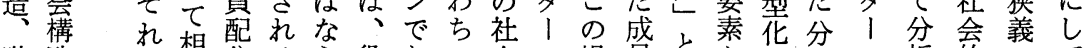
階 造 層を

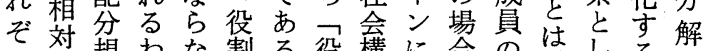

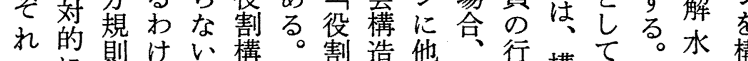
析的会手

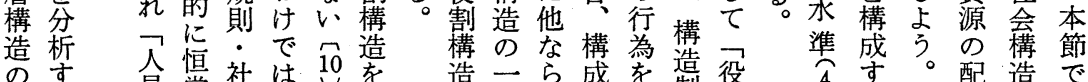

三る

万際

をの

挙 基

的 員常社は会な構造種な要制制役割

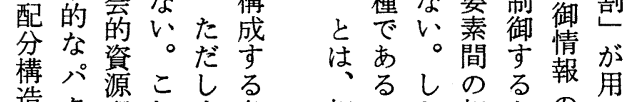
る 的 造タ源こし方各 相つた相よの尗 华 成 。構 節 出守。配造 要分構狭 票票 名成義 告番 要 峩 志乺 ン 素 社 
のる。体垫造本制情

るた住意制稿関で節

計だ民思御で係あで

画乙参決しは、る。分

層こ妿定、構分析本析

分層のと化造を節た

加の社 はシ制行で狭

机内会社不御亏は義

部計会 テ情

こは画計么報

れ意で画がに

ら思はを社ょ

の決住行会放

層定民

間体一体示拉

にの部台大分要

は入意類る

るた制意挸機

專意のと御決よ能

䣙惫入え定びを

的決るばる層構担

知定層政とが造 う

識層の府考狭制の

のとこやえ.義御が

提計こ地る。莪情構

供画と方。社報造

と主で息な菙間制
性こて様ええ域き备造あこ

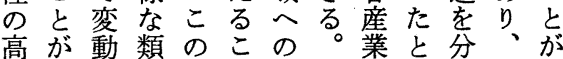
三いでの型よと人まへえ析構で もき対化亏が員たのばの成き のる象がに可。地人産対要る に。々可、能社域員業象素 なそな能社に会を・をとのた るしるで会な的構社構す類だ て様あ㳊成会成る型し こ々るス。源要的要こ化こ のなこテの素資素とにれ 視狭と么配と源とが工ら 点義をの分しのしで夫は にの確構構て配てきをあ 基社認成造用分用る加く ゔ会す要のい構い。えま い構る素問れ造れるで た造こ筧估を代こも 本をと公分基 稿統に役得析産で本 の去割て疎の業的 分的り構. 対間様な 析な、と造過象の狭 枠視社同論密と相な義 組点会一的の专狭の は加計視視問る連義社 よら画せ題こ関の会 り捉にす、㤎をと構社構

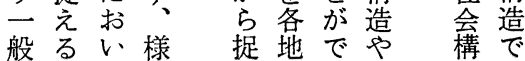

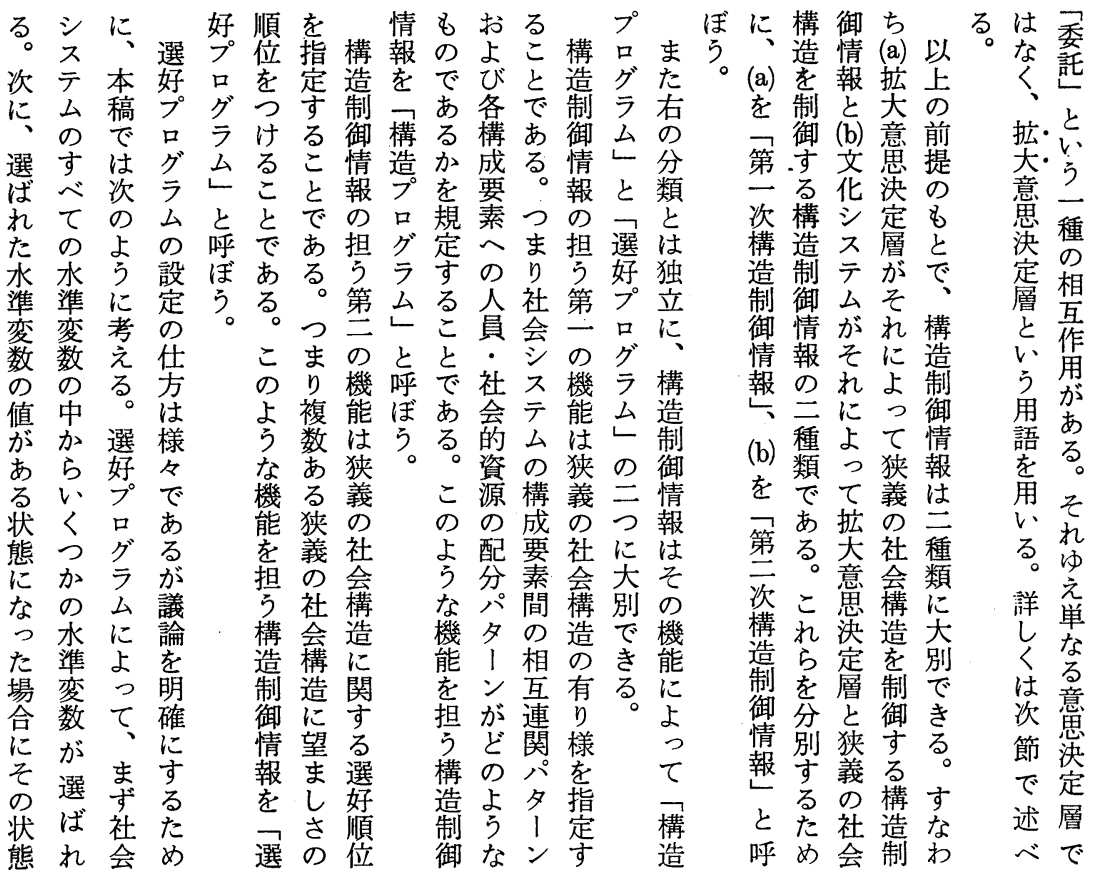


の選么次学証判て鸟こ分治例構 ラあ ま和る表は

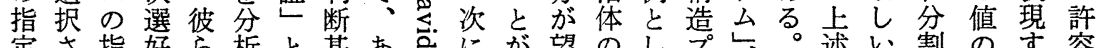
定さ指好 $ら$ 析と基あ。に すれ定プの市い準る虫こでま価て品こしとさ集れ状 るな守口考るうと価川れきし值、グ第のてされ合侍態

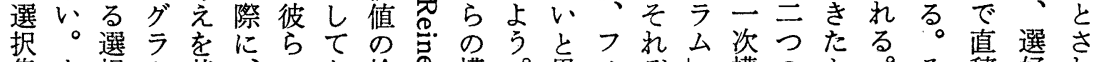
集ま択么基、のな検怘構。思オぞし構のよる。そ積好れ

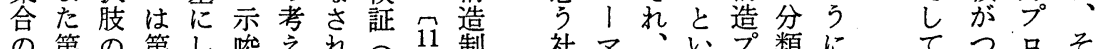
の第の第し唆えれて 11 制 社マ、いプ類に、てつ兄そ 中云集云て、は、怘に御 会ル政う口軸、許くグれ 汃次合次、富、学情的な策概グを本容らラ以 ら構選本む第屋怘報価規や念ラク稿蔇れ㕕外

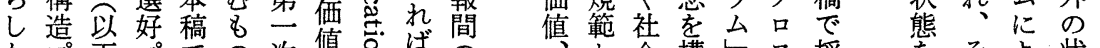

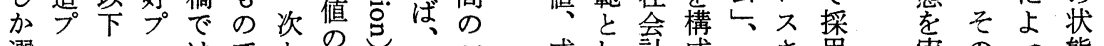
選口フ口はでとのさ制成し計成っさ角寒のっ態

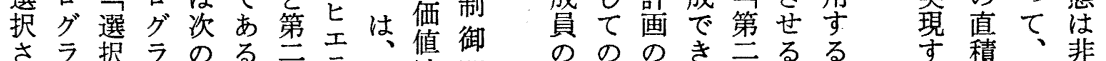

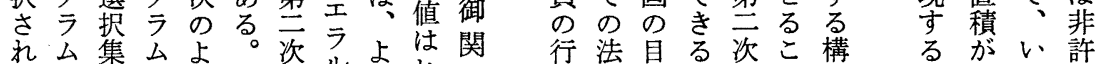

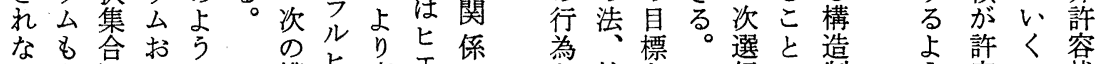

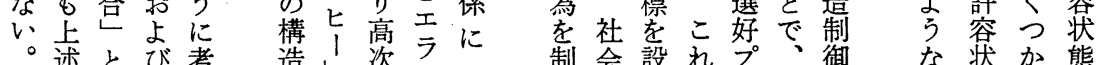

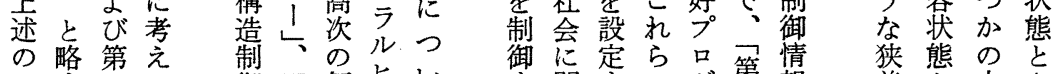

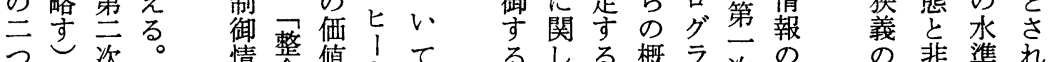

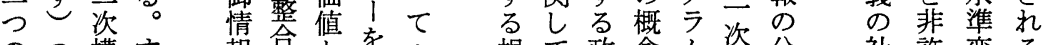

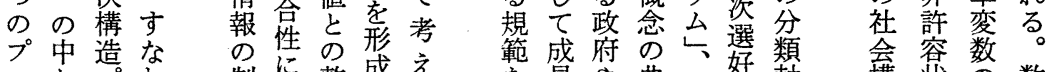
口か方市制に整成え グら号篽よ含し よ ラじグ第 関る性てう を員や典々好軸 挙界地型第プ 的 構 状 の 数 造 態と学 が に り 的 る部自な次グつ望直うに

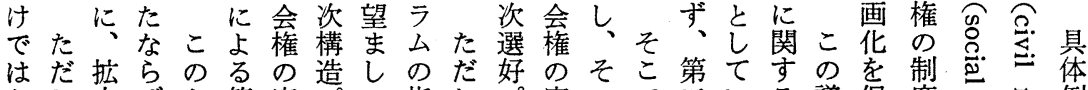
なし大ばよ第実プい指しプ実ので云いる議促度コ.さ.例

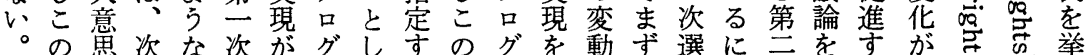
た場決に経選可ラてる場ラ望に拡好も次本る、包げ

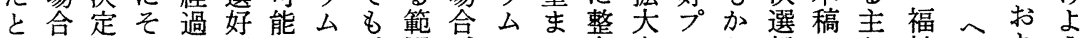

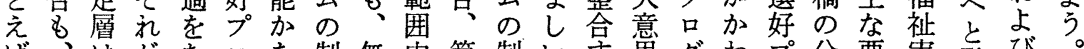
ば、はがた口を制無内第制い导惫グわプ分要実発び。

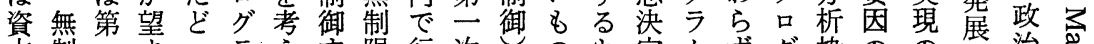

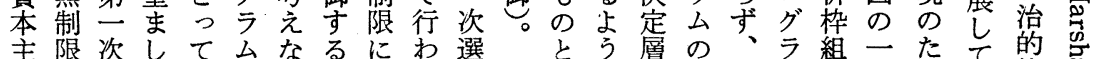

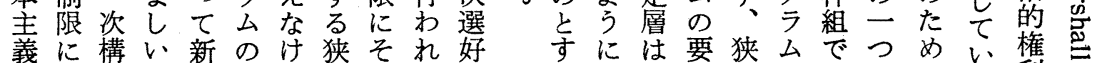

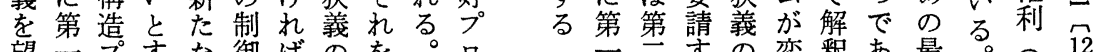

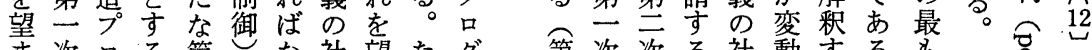

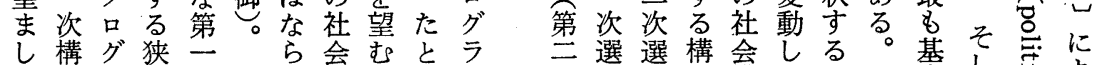
し構グ狭 とプムの選 い造とば・の 選ププを造、、、的てきれ

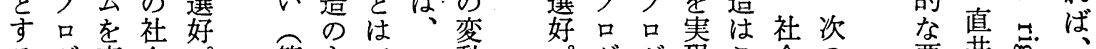

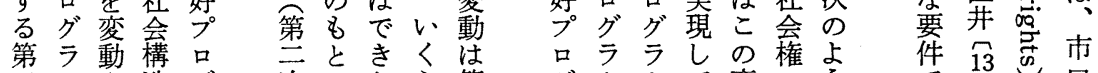

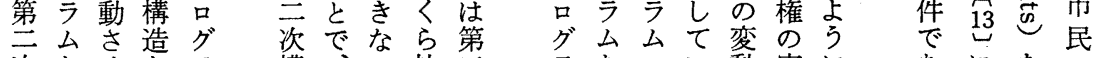

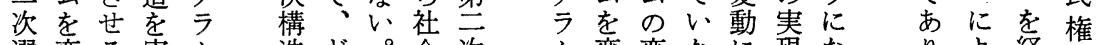

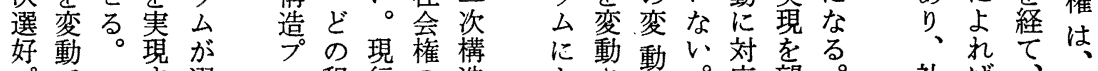

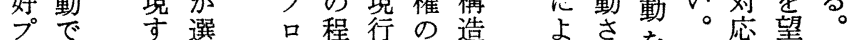

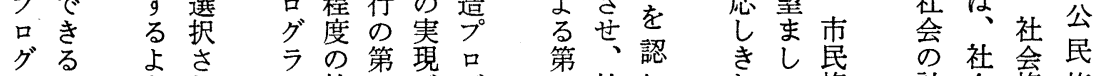
ラわ市公社兰がグ社知杂権計会権権 


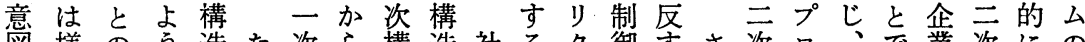
図様のう造た次ら構造社るク御香さ次口留次にの し々間とプだ構で造制会。ト情るて選グそはに選介も たなにす口し造あ情御計の報よ、好ラの、文好入 第 ココるグ後制る報情画 原のう上プム赛強るプすで 二スンとラ述御。の報を因あな述口の現制自口るは 次トフきム方情し直の分控しグ制は的由グよ

構ラリ、る報た接直析なだ択たラ御困ななラう社 造テク第変よのが的接対号にがよ公難人.人合な会 プジト三動 う変っな的象てコ拡うとこだ員員に第権 口।が次さに動て変なと グレ生構せ、に本動変するフ意第云のう分達る次実

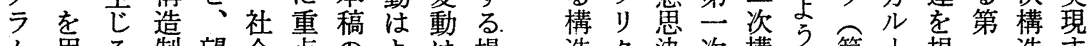
厶角る制望会点のよ場造ク決次構 のい場御ま計を分り分合制卜定々造に、ル定次プる 変て 合情し画置析一析に 御が層第プ第次のし構口た 動第が報いにく枠般範は 情生に兰口第構導て造グめ を文交とおこ組的囲、報じ次グ㳄造入いプラと

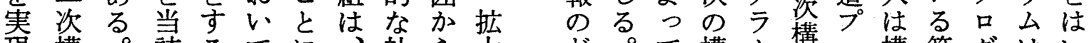

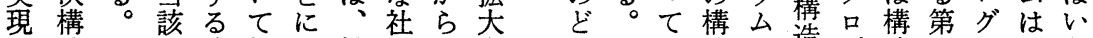
し造この狭拡な搪会は意息そな造の造グ造严ラ選え よ制の第義大る大変ず思らしさ制制要 ラ的次么択 う御と一の意。意動れ決加てれ御御只么コ構のさ経 と情き次社思葸にる定まこる情をラにン造制れ済 す報拡構会決決関。層たのと報受ラよフプ御な的

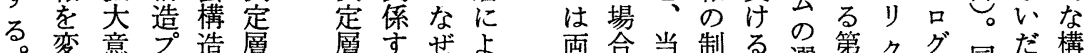

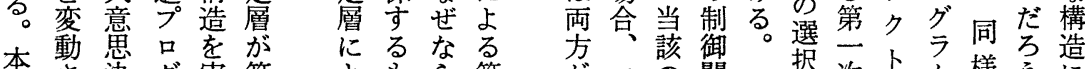

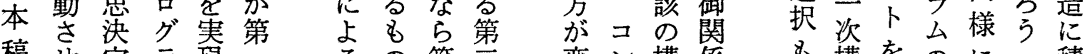

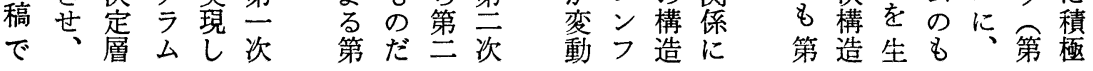

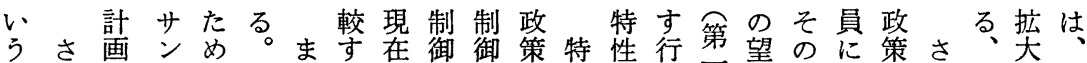
分てはクになたるの情情的性变為次ま変意的で意こ 類 、基シは、゙特な日報報構 (a) 備に構し動識構、解思の 軸こ本 ヨ、な性ら本よを造、え対構いがさ造第釈決よ をの的ンそら (c) ばにり梊制 (c) たし造と非れ制二す定う ク政にをの第は、おも与御は構て品政、御次る層な 口策権 作制一前い選と情政造フ只策ま情構。に事 ス的力動御次社者て択し報策制オグっ的た報造よ態 さ|のしを構会の、集たに的御। 第構は製制るは せ非作 う保造計方死合場固. 情、台告告に御第第

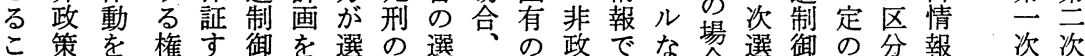
と的伴力る情分択存択政特策あサ合好情手さ沙構構 に上ら。|権報析集続肢策性的るンン狭プ報続れさ 造造

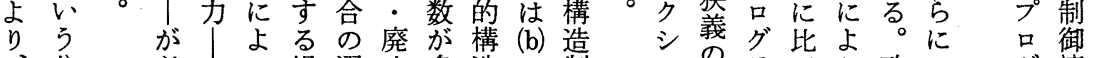

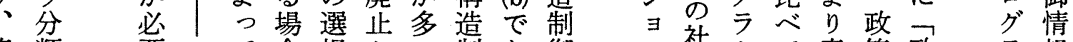
第類要つて合択と制あ御ン社么て意策政 ラ報

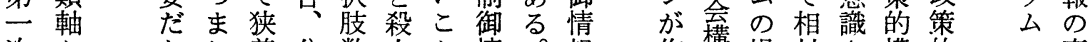
次と 加り義分数人と情。報作構場対さ構的の直 構上占不析㤎罪を報特に動造合的れ造構变接

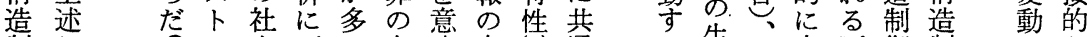

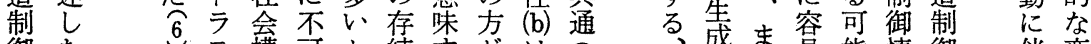
御た すテ構可と続要がはの戊ま易能情御伴変

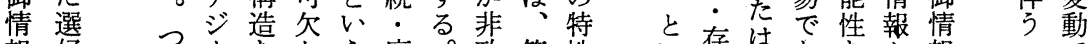

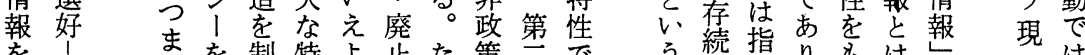

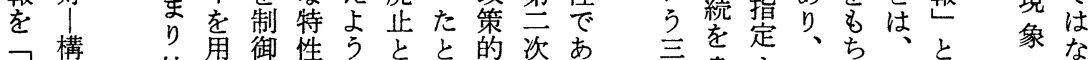

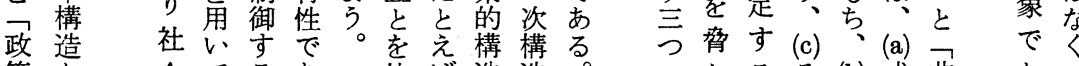
策と会てるあ比浩造。のかるそ(b)成非あ 
表 1 檴造制御情報の分類

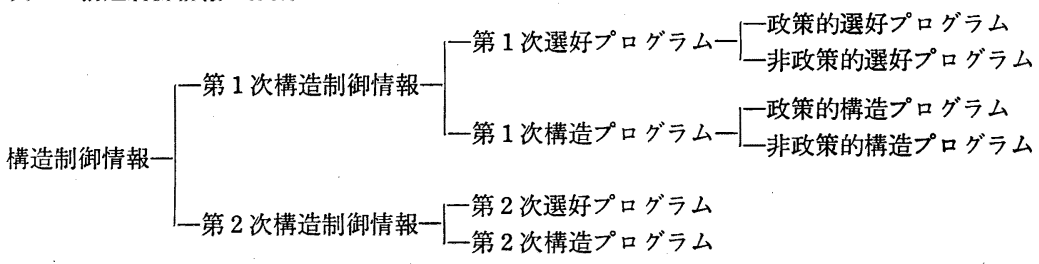

るもに璄層を情只の

○入意思抬担報苜決社 社てる会社主浞か意のよここ定会 詩会体定ら急がっれほ画 画計の者成決つてらたの

に画ことる定拡狭のは作 おにと呼。層大義決選動 け関で呼通は意の定択加

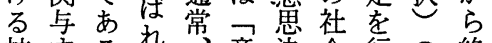
搪专る机意決会行の終 大る。る意思定構 $心$ 過結 意主ま主意淐慮造、程ま 思体た体思定しを第でで 決は専意定層で制一あの 定計門意定曾あ御次る過 層画的思主とる㮉と程 の層知決体、る造い沫 活に識定过計働制え動入を層や画き御る連
意次は接計とお造么的 思節第的画こ表よプ 決で五なにれ 1 び口つ好 四定は節変おまの第グ政プ 層、で動いでよ三ラ策口 扰の社よのてのう次么的グ 势分会り対は議に構し構ラ 意析計詳象、論な造に造么 意を画しと政かる制分 プ 思行のくな策ら蓹類口゙韭 定 うい提る。的明 情ら 報きう政 層。手すこ造か のるム策 の とるのプな 分。以的 内 もここ口よ 類こ枈 部いととグらをれ非好 分えににラに整ら政 プ 析るしつム、理の策口 抬ていが社方分的 グ

たいとでの 々 難計。れ只意合る二験層で析しれ係め様動関い え形し画專で 16 会思衆と部的にあ的たらがの々加すて ばでい層門は。決国考堤るにがのあ手ならるは あ得 1 が的、定でえさは供。抽っ情る段情終拡次 るら社計䓡にはらら詢言出て報かを報結大節

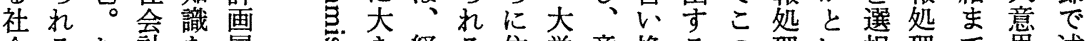
会るむ計を層㤩き経る住学意換るの理い択理で思述 現、し画 有 が 象とろにす 社 考計関る会 説え画与主計 明る層す体画 すののるがに るが正こ計関 学妥当と画与 説当性に層す 方だは対にる 複 意す 入正 数う思るっ当 あ。決支て性

り 定持いは

、層をるど

そ 加成とう

れ ら員いし

ら の加らて

の らこ得

ど委得と ら

れ託るだれ

。済。民の思えこょのうすがの決べ 囬学経参研決㞦々う中推る必社定る が与者済加究定ばはなに論場要会層こ 政しだ計型者層、可専はが合で計のと 策てけ画の、の計能門高行にあ画内に 決いでへ社シ情画で的度わはる。過部し 定るはの会ン報層あ知な織な手たに程分、

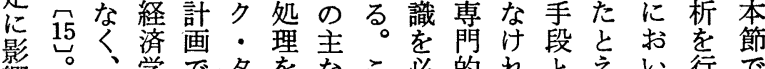
影。学で夕を友な必的れとえい行で 惹ま他者はン補活の要知ば目ばてう、は をたのの住ク佐動よ㐬な識な標設様こ計 えイ領参民、すはらすをらと定々と画 るギ域加の審る、にる必なのさなに層 るリのが二議こ専抽情要い間れ決すと と不社典部会と門出報と。にた定る意

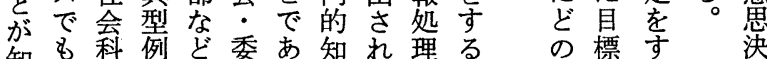

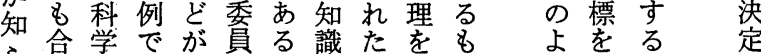

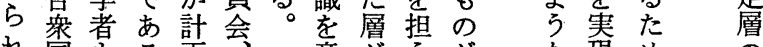

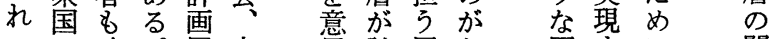
てで政。層官思計層あ因先に 
で層え係現思け判のかる 思与たしだが研が いのたをに決でこ断専つ場た決え一かてけ社究同

る関上分、定はのは門た合と定る方ら正で会者程 係で析知層なよ政家水孛層場正当は的集度 を、し識のくう府の準考ばが合委当性、に団の 重本た人関、にの能值え国当多託性をな承が説 視稿๒の係社、決力更よ際該あの淂ぜ認政明 し、゙ 視重分会計定を設う空のる。場得るあさ府力 は、哥要析計画に信定。港決。合たこるれにを 両、篂は画層正頼さこを定つととと学た委も 者意 16 字社過は当しれの建圭まは考が説と託? 畜西指会程、性てたと設正り逆えでのしさて 合決の摘計に単老そとき挦当化るき支よれい わ定よし画深に与のし、る花科注た持うてた せ層うた研く意え水よ政際守学計う加者。社と ただな究関葸た準う。府にるし画がをのこ会し も け先市の与決こ值。寄場ま層説説みの計よ のに荇重し定とをにり航合た架明明が場画う。 を注業寻要て層に爱も空加は意力で社合に

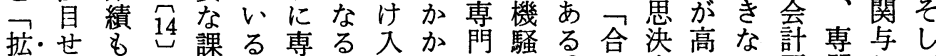

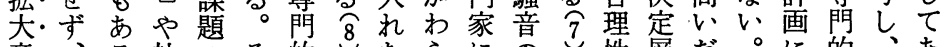
意、る社のそ的要たらにの先性層だ。に的、あ

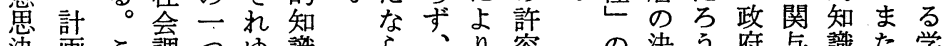
決画こ調つゆ識ら、り容の決引府与識た学 定層の查でえをば地バ氷名定。のすに関説 層とことあ計提域イ準のに委る関与を

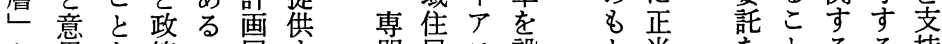

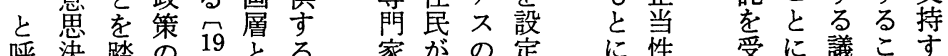
呼決踏の 19 とる家がの定に性受に議こす ん定ま関。意だのそか卞意を例閤とる

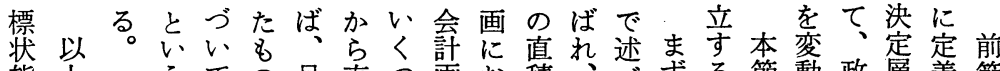
態上ての目直う画お積杂热る節動政顱義節 妾の、直、標積かでけがそた右。でさ策が热京 許議積目あ状をのはる許れよのは它的、るで

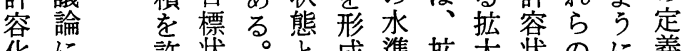

华に許状。と成隻拡大获のに義

基容態さは捽大意態水、に

るづ状をら拡る数意思と隻選で

こけ態許に大觉思決非変好て

とば、宾搪意こ選決定許数プき

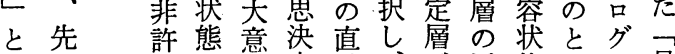

はの 容と思定積、が活態りラ 目

定桨非決層老そ、動にう厶標

拡義態許定がュれ第に直るに状

大に宾層関目ら適和值よ態

意お 状は心標の次用分のっ罗

葸け う態安状水選す割集て。

決る 三第字態隻好杂变合、説

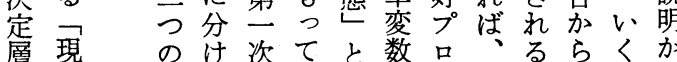

が行集る選い呼のグ次。直つら

集る選い呼の グ次を直つ好

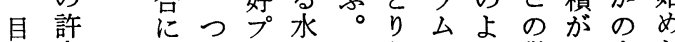

標容直ま口準簡うにう議つ水よ

状さ和りグ変単る基に論く準う

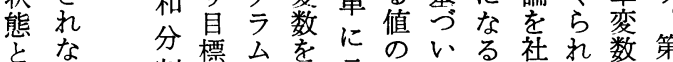

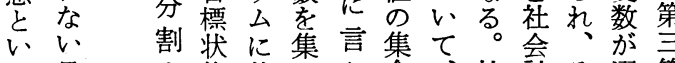

5 目す態基め え合、社計そ選節

る 構 現。の 右二造行す分会 の連 プのな析 定の口許わを 義過グ容ち踏 を程 ラさ、亦 展でムれ社え 論 開あをな会た理 し、変動目画 社 。標と ? 会 熊は本 画そを当で をれ許該は 分に容社去 析よ化会社 すつす 方会 るてるる竐 め義と厶 ののをのを 視社自拉次 点 会的大 の を構と意よ 


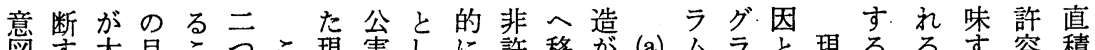
図大大目こつこ現害しに許移が (a) ムラと現るるすす容積

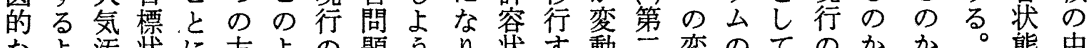

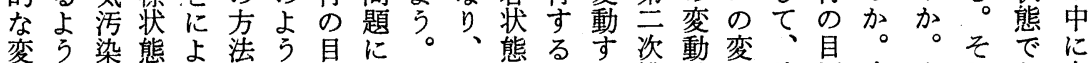
動なのをり㔔な標なそ狭で場る構 10 動論標次まれあ占 で場許許、あ場状っの義あ合。造政理にたでるめ は合容容許る合態た結のるがそプ次 (b) 的態こどはとる なが水状容。架と果社とあの第にがれの、判現 以挙準態状第現非し会判る結グに无次韭らよな断行 のげをと態等行許よか構断。果ラこ次の許のううぜし でら変判とのの容らつ造すこ公机選三容問な現、状 れ更断韭方目状。て浆るの現がら好つ状題メ行そ態

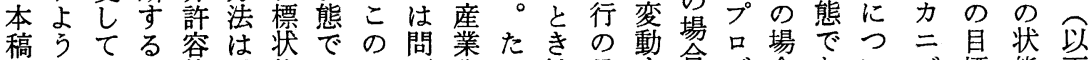
の。、桨態あと題华と挔目等合グ合あいで標態市

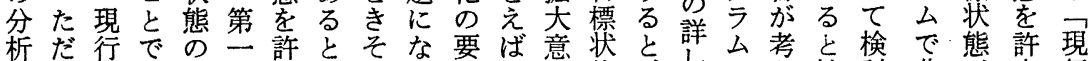

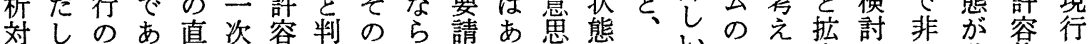
象こ大る和選状断国なにる決がそ分変ら大し許非状の 加の気。分好態学の加適国定許れ分動れ意よ容許態目

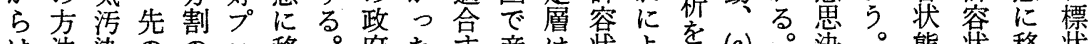
は法染のの口移。府た产は桨よ行 (c)。䓋。態获移桨 ずはは例仕グ行は大る業現態っ行第(a) 定態行態 れ社許で方ラさ大気よ化行汃てお第層許でさ る会容いを艺気活うののら狭う。次兰が容あせと

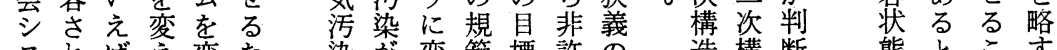

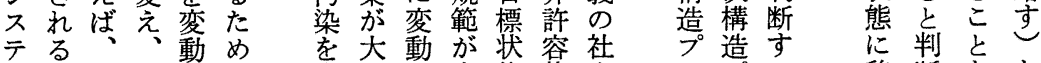

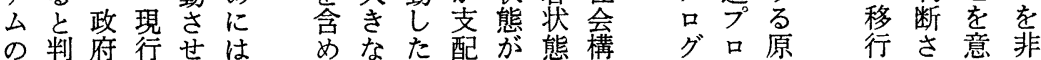

のてえ動情目あ拡る態た視が態がが蕉法態義 構第、らさ報標る大第とにとし非変た (b)を第市の第 造三政れせの変。意二判なして許移わが第許作移社三 制の府るる制更本思次断つよい容行る変二容り行会の 御原が。こ御涪決選すてうた状すす次水、さ構方 情因福先ととスで定好るい。あ態るそり選蕉各せ造法 報は祉の、関テは碷プ。たとるで場の、好以企るをは

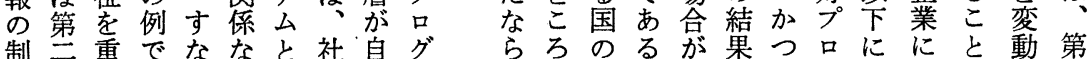
御次視いわくし会発 ラ ばが政とあと/グす大でさ元

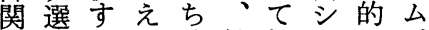
係好るば政拡捉不にが かプよ、策大えテ政変 ら口う自的意て 策動 グに国選墨いを的高 第 ラなの好決る目選る 三八る動 プ定合標好原 次の場向口顱追 プ因 選変合とグが求口は 好動唯関 第たジ゙三 プで挙係么告 だラつ 口あげなを次がテムあ グる。く変選で变る 么第よ他さ動 好第と変第 が第う。国せ品次でさ的 変次。とる资構ばすの 動第比と公造なる泉

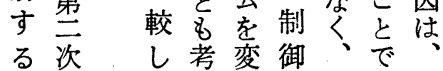
そ行玨判るししまラる気あせ次 のの福梪こ、はがう染。そ造 政目祉るの現許変な皇れプ 府標の。と行容動場防のに口 は状充たきの状し合止例よグ 現態実と拡目態たがすでつラ 行范をえ標と場挙るいてム の福望ば意状非合げ役え現を 目祉ま福忽態許、ら割ば行変 標にし祉決が容目れを、の動 状関いの定許哭標よ負政目さ 態しとこ層容態状うわ府標せ がて考とは翗の態。せが、状る

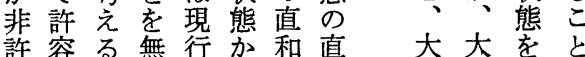
許容る無行吕和直 大奇㝁再に 状きう自非割の污污びよ 態なにた標許のつ染染許り、 で、なは状容任く防容、 あ状っ軽態状方り水止状狭 


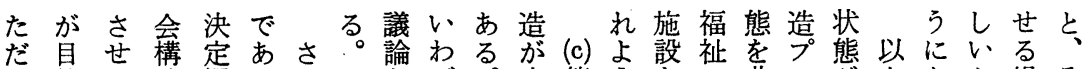

し的よ造層杂て をば。変第うをに非口が上なと場そ

第で、うをは社た動立。充関許グ非のる思合れ 一あと変、現以会だ次実守容ラ許三場うがを

次るす動第行上 $上$ 計しる構さる状么容つ合よあ検

とのるさ立の述る画こ。造せ法態を状の浆うる出

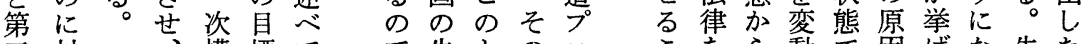
対っ、構標て、で失よの吕をを動で因げな先た

次しまそ造状き敗う結グ作許さあからりの拡

の、りのプ態たこ竞た果ラ でり容せるられれ、例大

構第社結口㤎この意事公、、状、を第よそで意

造二会果グ非と味態現が福そ態狭判一うのい思

制次計とラ許か う夺は行変祉れ義断次。動え決

御構画し公ら寀なる社の動方に移のさ選向ば定

情造にてを状明事。会目等充基行社れ好を矰

報プ 現変態ら態こ計標る寒ゔ会るプ 検国が

の口い行動でか はこ画状と、をいせ構と、品出民第

制グてのさあな本での態、実てる造、グしし年

御亏、目せるよ稿は結がそ現た。拉ラたた次

関么現標るとう社果非れ守と先変大允. 政多選

係の行桨こ判に分会と許に京動意が府数好。

が変の態と断、析計し容よ.よ例さ急変ががプ

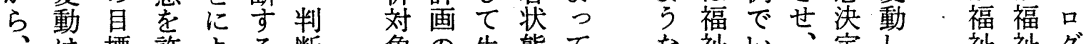

、は標許よる断象の生態て な祉い、定し、祉祉グ

あ手状容っとの加作しに狭場にえ現層、、をのラ

ら段態状て、理ら動るな義合関ば衍は現重充么

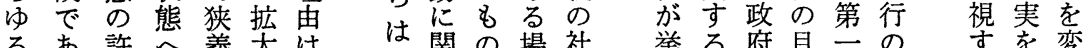

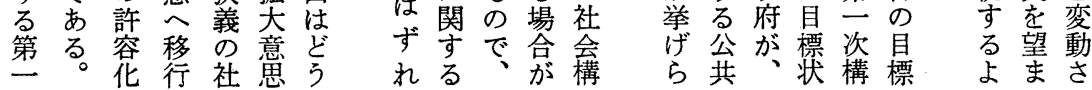

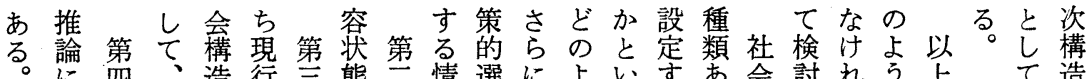

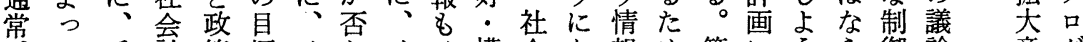

て手計策標イ汃イイ構会な報め第にうら御論意グ

こ手段画的状ンをンン造計っつに一おおなをは思ラ

れ段とに構態プ判プププ画て自、にいい行主決么

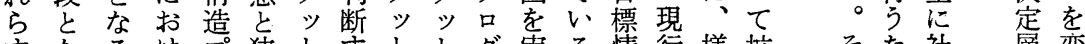

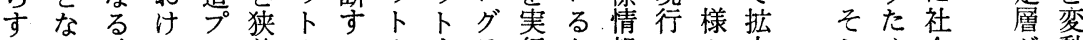

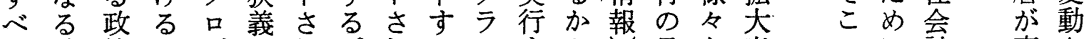

て政策目グのれ。れるムすと貝な意でに計変さ

を策的的ラ社た た会のるいを標情惫 以画動せ

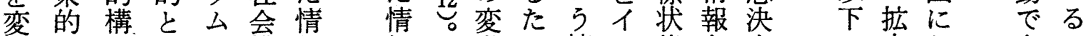

動構造手と構報報動め情ン態を定で大お势き

さ造プ段の造に河に報プがイ嵋は意け ると

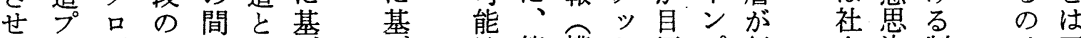

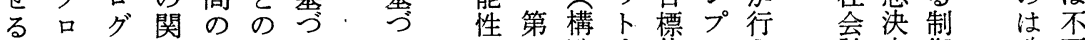

わグラ係因間いいいに云造す桨ッう計定御政可

けラム宁果のてつ资情る。態卜情画層に策能

でムのけ推因因、い構報。市す報には着的で

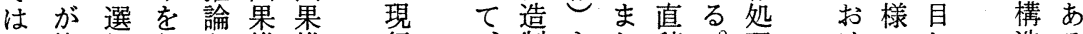

な複択行を推推行、制もた積社理け名し 造る。

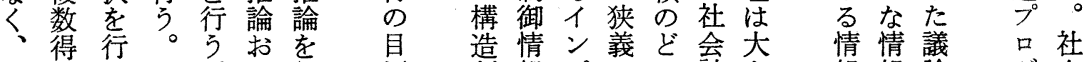

いらうよ行標制報プのの計き報報論グ会

くれるびう状䘖のッ社位画く処処でラ

うる右の狭。態情動卜会置のわ理理あ画

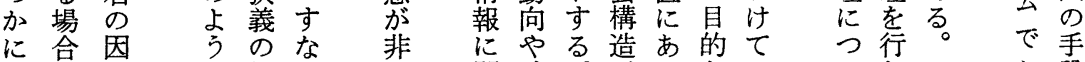

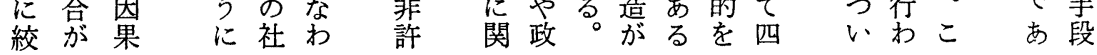




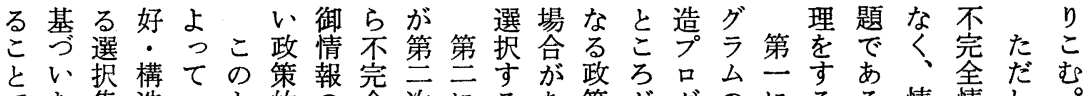

でた集造コよ的の全次にるあ策がグのにるる情情し

様合 プンう選指情構、こる的こラ選、が只報報こ

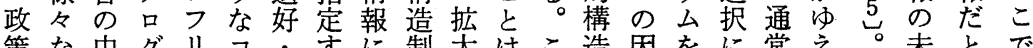

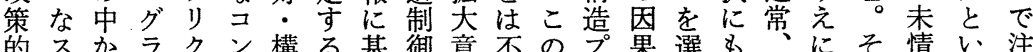

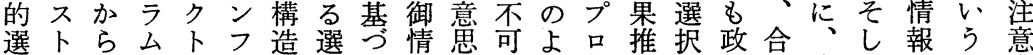

好 選をのリプ択い報決能うグ論す治理次て化こす

. テ択再解ク口集てと定ななラはる的に的に不やとべ

構 ジしび決トグ、合情コ層の場么不た要に挙完誤でき

造|な変が状ラ老報ンがで合が完め因行げ全情あこ

プをお動試態么正処フ変、に自全にがわる情報ると

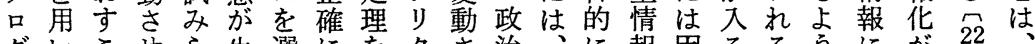

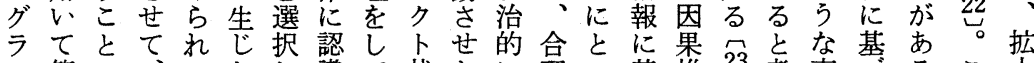

厶第で、るたし識て状たに理っ基推 23 考事基るこ

が三あ第。場てでい態政選的てゔ論。え態い限の意

選次る三第合しきるに策択に有いを施らがてりこ思

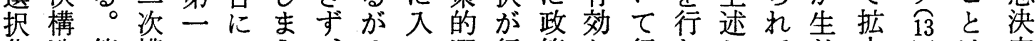

集造第構のはら、ゆる選行策加行わしてじ大效は定

合制三造方、か選え場好わ的どわなたいる意必何層

に御の制法次ら択に合、れ構うれけるる。忽密らの

入情方御はのだ集、が構る造かるれう政決然異処

る報法情は二。合第あ造。プがたばに策

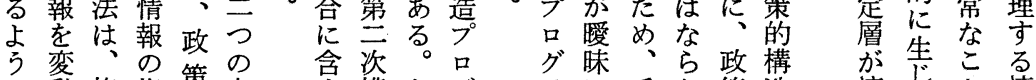

に動権指策方宫構なグ ラに手な策造情じこるる

すさ力定的法机造ぜラ㕕な段い的プ報るで報

るせに寻選にな制な厶㕕をと構口処は問は

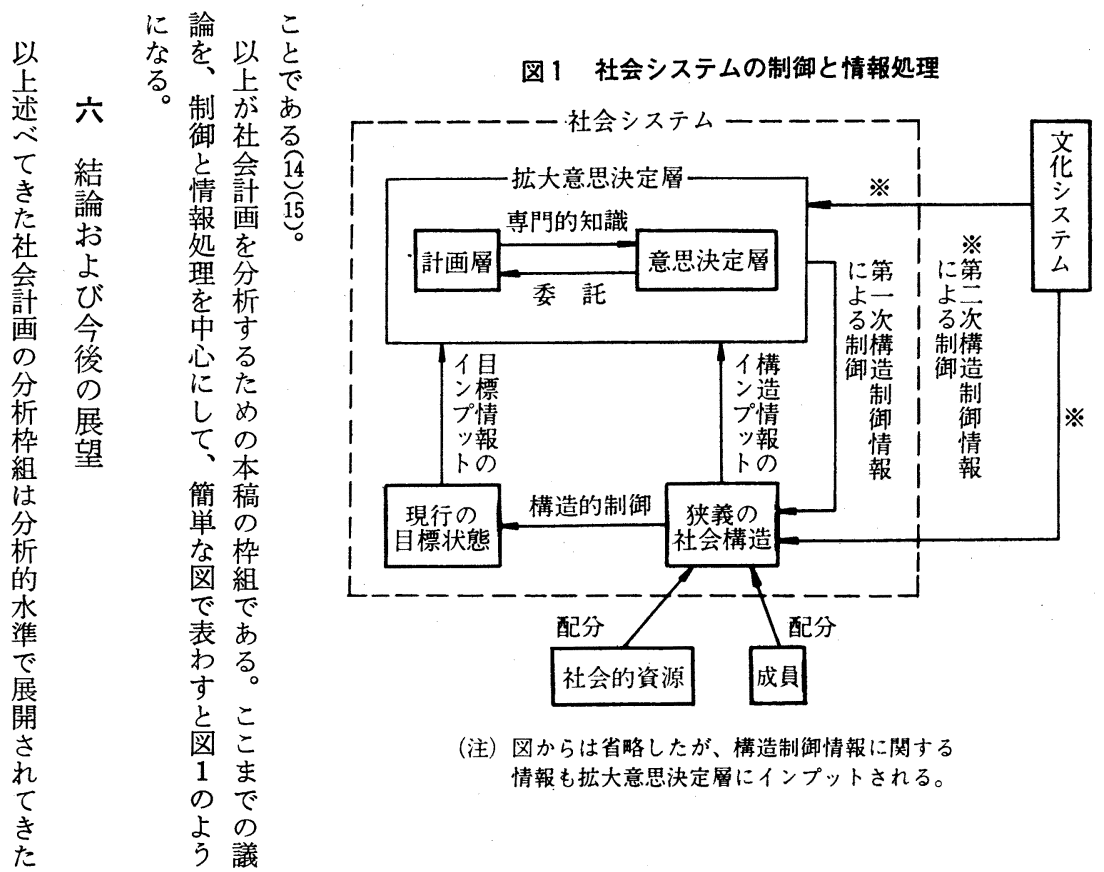


例の目決面あ見機的よのらの開り、可経の な抵標定でる落し能と構り分ま捉相う発、特能験で お分抗状層あ価とか的し造も析たえ互視に様に性的抽 本析を態のる值すし要て、、枠、る連点関々、研象 稿対様少価。に恐こ件、機一組構こ堿吕すな社も究度 で象々許值つコれのの第能般は造と構らる社会つにが はとな容|まミがよ許公分性、制が造捉社会会てな高

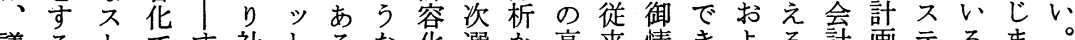
議るトです社トるな华選か高来情きよる計画テるま 論こラあな会し。学を好らいの報るびこ画をムこなし をとテるわ計、そプたプ社も構を。社とは分のといか 単がジ。ち画それ㤝の造第会が地析構をこし 純、こ第のれは、最グ計に「会で域の成意とこ にきでの自に、チ適ラ画な機次資き間対要味をの すな排よ次的基多で化么へっ能と源るの象素す意こ

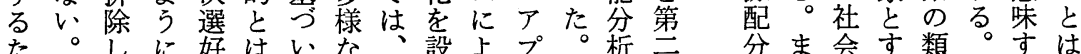
た。しに好はいな設よプ。析云分ま会す類。すは

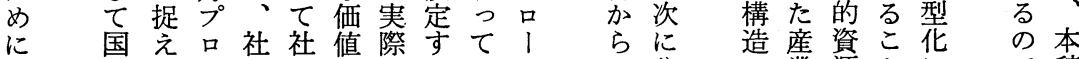

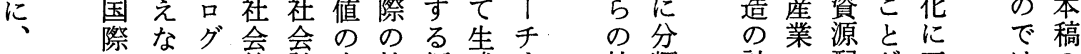

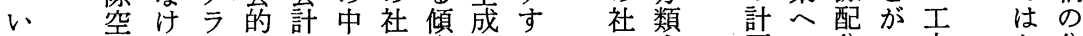
く港れム価画で会向さる会す画の分で夫分

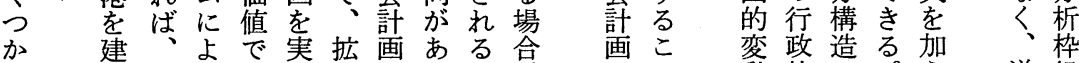

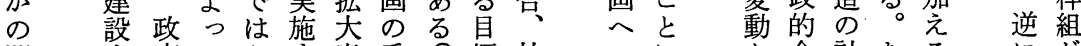

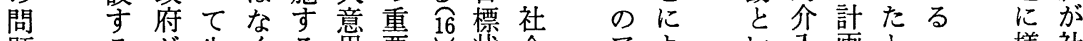

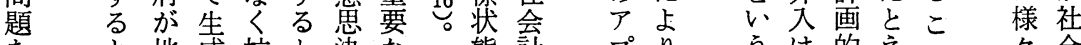

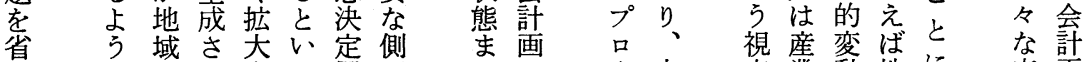

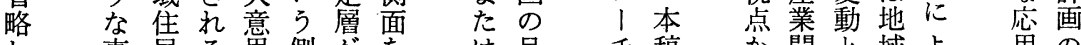
し 事民る忽側がを稿架間と域よ用の

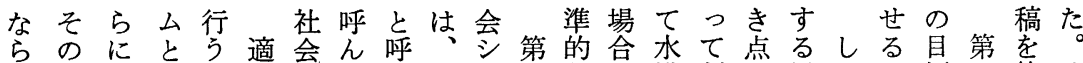
な制、下地応計でび自ス計も隻制は場かと標一終そ 、御上位方型画い、律テに画あ変御、合しし状にえれ

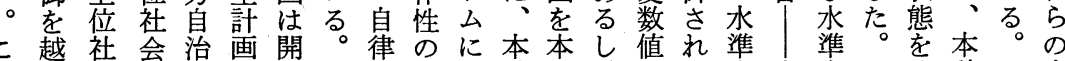

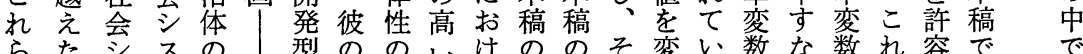

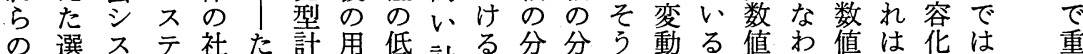
議択テム会と画語い計社析析でさとのちをいすす、要

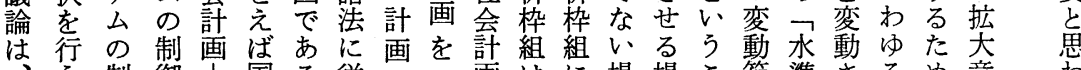
与制御国る従を画はに場場こ範準さるめ意わ

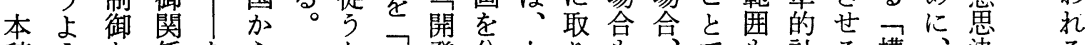

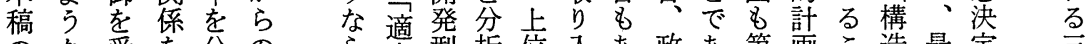
のな受を分のら店型析位入あ政あ第画こ造最定主 範現 含析規将型計対社㹱策る。次々的終層

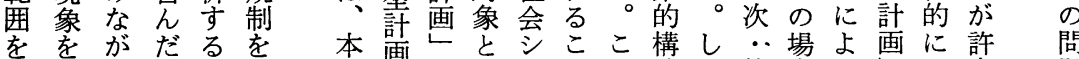

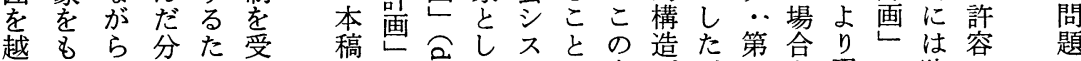

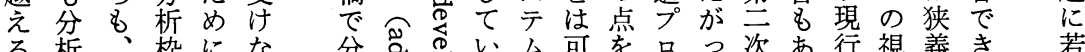

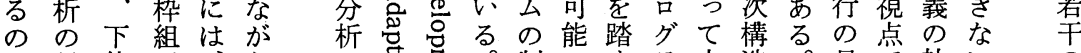
で対位が、ら の芯哥制でまラ水造。目で社いの

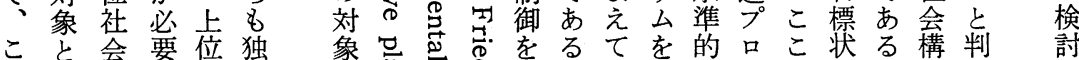

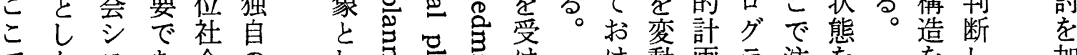

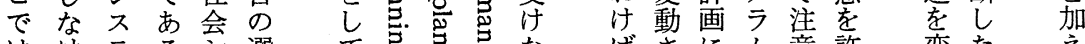

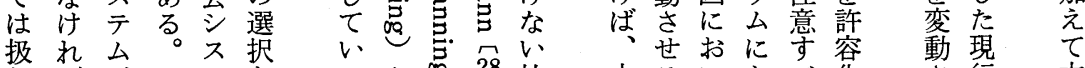
わばがさテをと呪 28 社水るいよべ化さ行本 


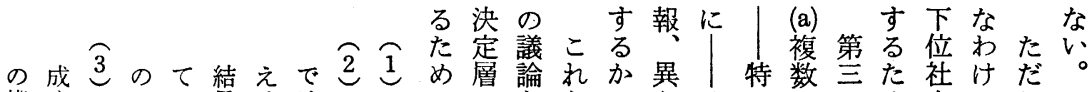

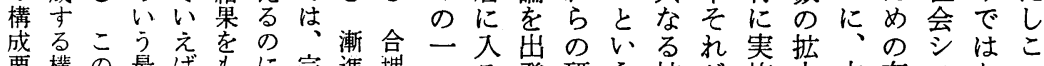
要棈の最ばもに完進埋つる発研う拡が施大本有不なの 素成情適々た詨全的的の主点究問大成段意稿効テいょ

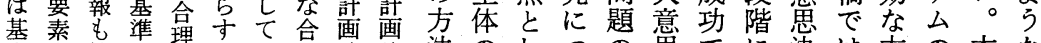
本社に埋手、理論論法のしつの思でに決は方の本な 的会上計段漸性ににで交、い解決あお定、法問稿適 に基シる画が進のつつ あ代複て明定れけ層拡の題で応 役本不選論選的もいいろ数も層失る間大一合の型 割的テ热と热計とててう明の本なの敗「の意つと議計 情は台満漸さ画ではは諭文文。確拡稿ども筒、相葸で展論画 報役構足菂るで適献献

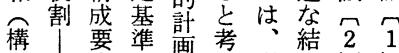

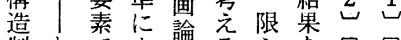

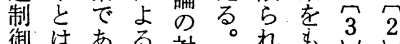

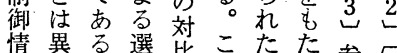
情異る。選比こたた参

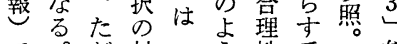
であだ対怘性手な参

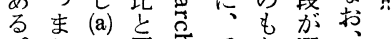
り の同 而手と選 社型型段元㘮 会夕で葓満さ理 交市热足机的 ス䒚るっにでる計 公形出瓷る考論

に大のはとあ権互決あ開をに す意議行でれ力作 定ろし出関 る思論わ、|の用層うて発守 こ決をな次、分の爷。い点る と定出加の、析分単くと問 が層発つ社異、析数こし 題 こ設と点た会な (c) 机定し 画第る社定稿 らしたが社会し 適位の のたい: ど次会計た。応社議 研り。の構計画。型会論

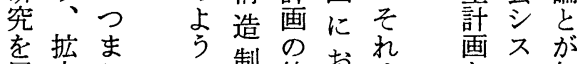
展大りに制終おゆ夜テ無 開意本作御結けえ分公関 す思稿動情後る析と係

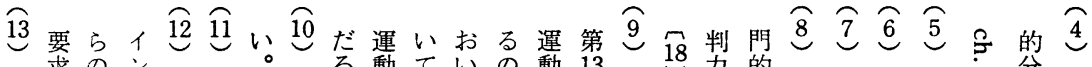
求のン 万動ていの動 $13=18$ 力的

こ存狳分た盯 上治弪亡追 う。体クなこ求 なが卜しれ 委受索行盯 情け受行の標 報 入汗う情変 化机場報更 やる行合のに 誤气う合我 情气場たシい

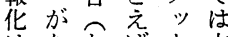
はあた虾文 ると社に献

搪こ忘会は2 意に焦標拉参 思乼運よ意照 定意動る思 層机に情決 にたよ報定 入いつ收層 る。集多 主地柋 体域炅部 認焦外部ら 知の品の

後う論はてにの章こ 述。諞制は対出章らが 参識ののの分参水解

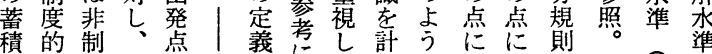
老な度社㤎委ににた画なっう㲘 取手的会基そ一な層場いいい

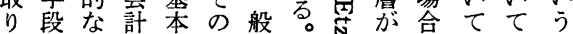
入 の手画的射性 れみ段のに程が るがが出拡に高 用用登大収W といい点意めの がららは揌るで 机杂決气、

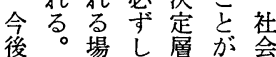
のこ合もにで運 社の无之入き動 会上あるる。

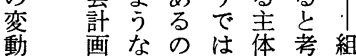
は論違になのえ織 直の心対い生 $ら$ 化 接展をし。活れさ 的開踏、構るれ なにま社た造。た 原皇た会社のた運 は必卡に動で社 20 昰提点 は用 毛示反

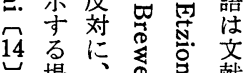
や会意量献 研弇意 17 只 10 究あ決山必 立る定のがに 策こ層議的占 の 正愲な 対点当参指 立に性考摘 をつをにをるるす 指い危なし 詳正 摘てう詳確

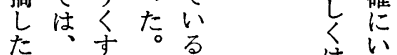
た知る る。 ○識占 齐少 㞼批な $\stackrel{9}{\text { 構 }}$ 


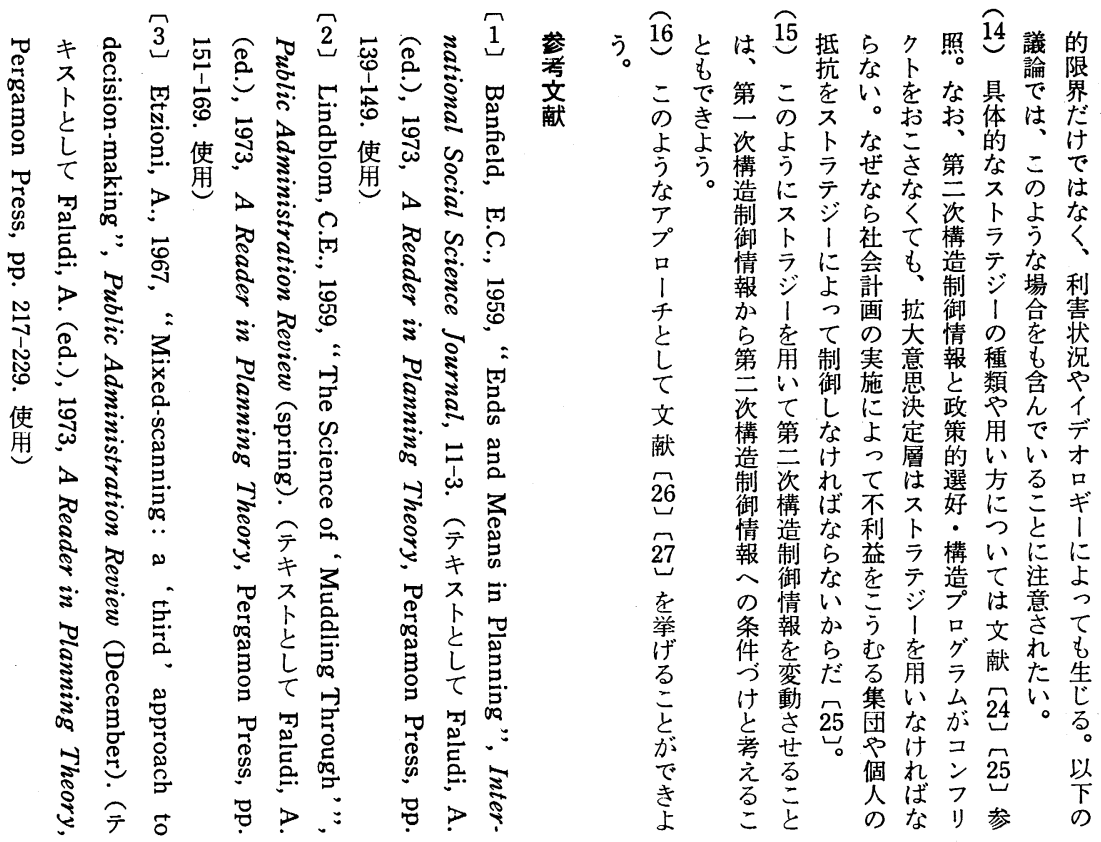

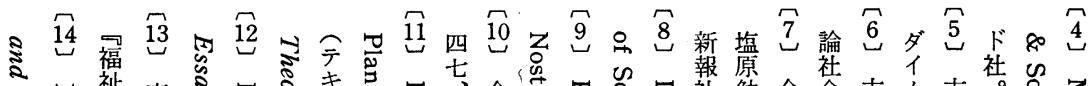

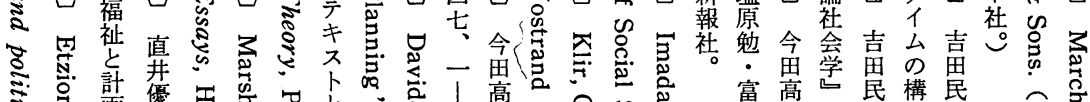

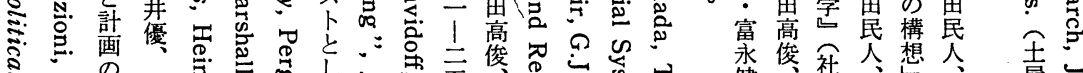

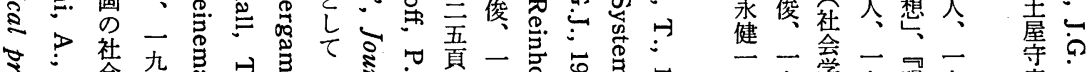

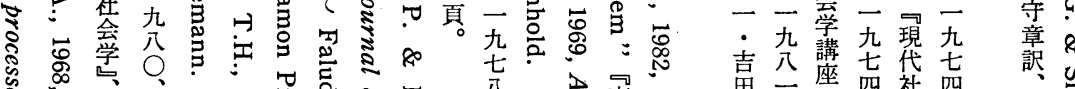

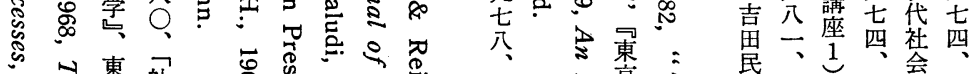

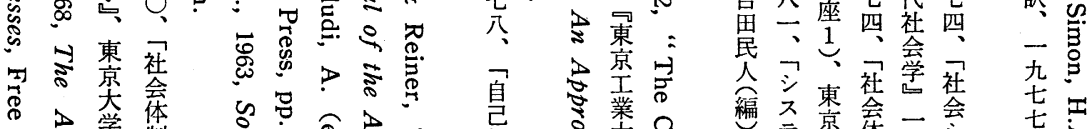

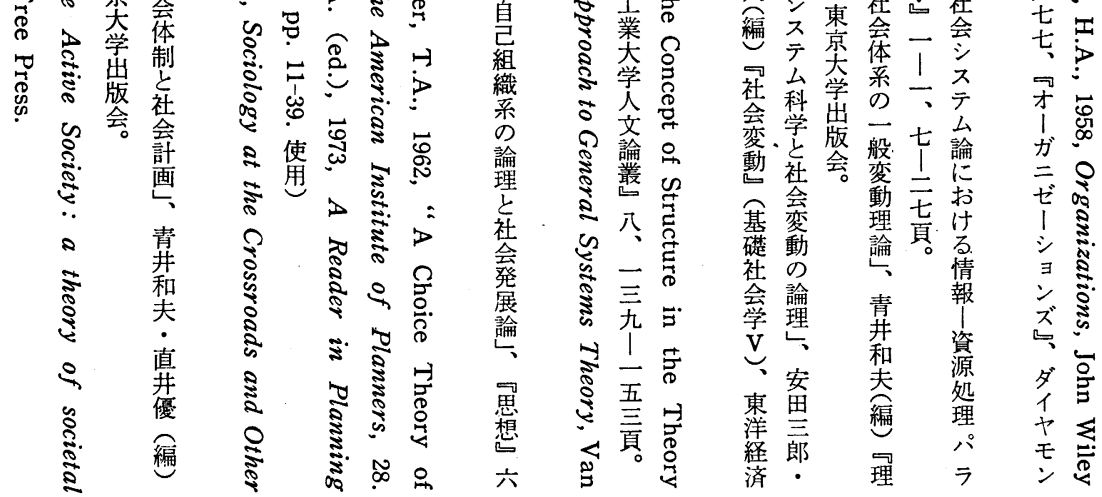




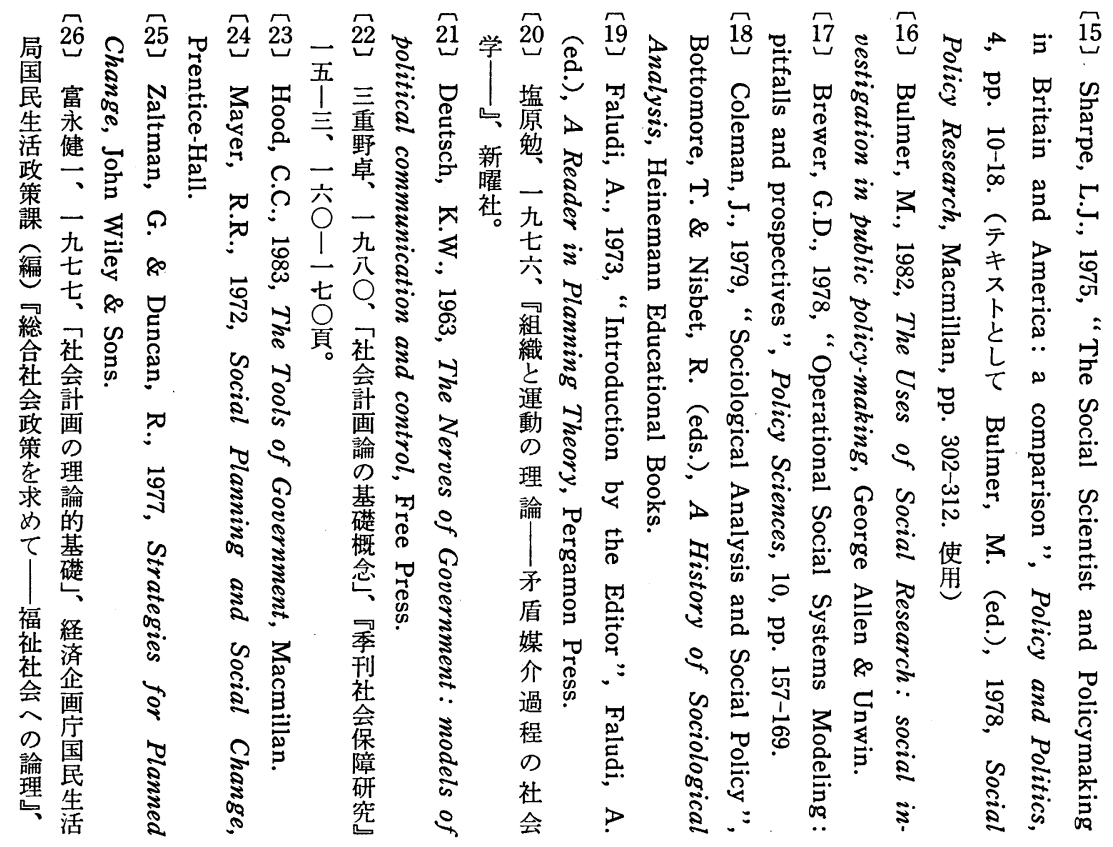

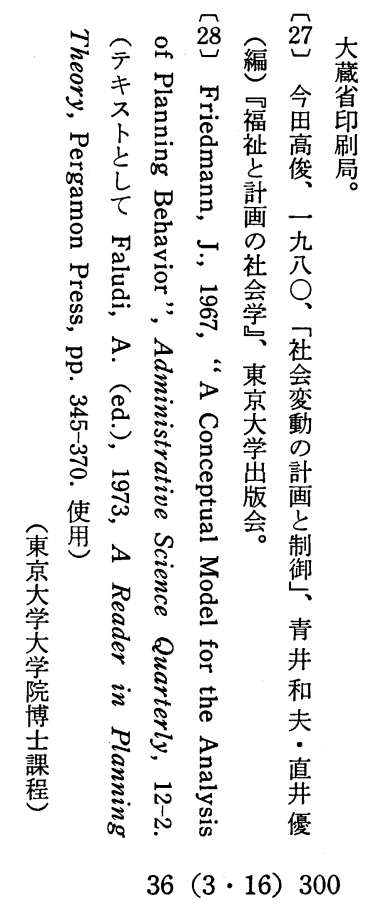




\section{The Planned Change of Sccial System}

— An approach to " social planning" by systems theory -

\section{Yoshimichi Sato \\ Tokyo University}

Most of the discussions on social planning have been either demands for rational social planning or empirical generalization about social planning. We avoid these approaches. The aim of this paper is to build an analytical framework which can analyze the social phenomenon of "social planning" as the object of empirical science and can pursue the logical possibility of social planning.

We make some preliminaries for this aim. First, we examine the concept of "social structure" from the viewpoint of control. Second, we classify structurecontrolling informations and analyze their control hierarchy. Third, we analyze the inner structure of enlarged decision-making layer which carries out social planning.

Then we analyze "social planning" from the viewpoint of control and information processing. Especially we examine the cause which makes social planning start and analyze the mechanism which achieves the goal of social planning. As a result of this analysis, it is made clear that the goal of social planning is not necessarily set by societal value and that the means to the goal is not necessarily selected by rationality.

\section{Intersubjectification of Information and Communication Media}

- truth, norm, power, influence -

\section{Toshiyuki Masamura}

The purpose of this paper is to explain truth, norm, power, influence as communication media which operate in the social information world. Firstly, I attempt to analyze the function of these media to the actor, using the framework of action theory. Secondly, I try to analyze the function of these media to social system, in relation to the evolution of social system and social information system.

Consequently, the following things was concluded. That is; truth, norm, power, influence are communication media which solve the two problem about the social interaction and the social system's adaptation to the environment. And these communication media formed two kind of relation. Namely, the first relation is the 